\title{
LEGISLATIVE CHANGES IN THE LAW OF EQUITABLE CONVERSION BY CONTRACT: II*
}

\section{SIDNEY P. SIMPSON $\dagger$}

\section{IV}

\section{BURDEN OF LosS AND INSURANCE}

Perhaps the most debated question in the law of vendor and purchaser is that of the allocation of the burden of $\operatorname{loss}^{151}$ between the parties in cases where the contract does not specifically provide for the matter. This question may arise in a variety of ways. The most usual form of loss encountered in the cases is that resulting from fire which destroys buildings or other structures on the land contracted to be sold, ${ }^{152}$ but injury to the premises by flood, ${ }^{153}$ windstorm, ${ }^{154}$ or collapse of buildings due to natural causes, ${ }^{155}$ raises the same question. In no reported case does the land contracted to be sold appear to have been physically destroyed, ${ }^{156}$ but there are numerous cases in which the prenises have been taken by eminent domain, ${ }^{157}$ leaving only a claim to a money award. It is of course possible for the parties to agree that the burden of loss occurring after the making of the contract of sale and before conveyance shall fall on one or the other of them, ${ }^{168}$ or to make a similar agreement as to any particular type of loss ${ }^{150}$ and the common

*Continued from 44 YaLe L. J. 559.

†Professor of Law, Harvard University.

151. Commonly referred to as the "risk of loss." The question arises only where the loss, as between the parties, is accidental or fortuitous. When it results from the intentional or negligent conduct of one of the parties, the loss falls on that party. Thus, the vendor in possession is liable for active waste even though the "risk of loss" is on the purchascr. See Worrall v. Munn, 53 N. Y. 185 (1875), aff'g 38 N. Y. 137 (1868). As to losses due to the negligence of a party, see note 178, infra. As to permissive waste by the vendor in possession, compare Royal Bristol Permanent Bldg. Soc. v. Bomash, 35 Ch. D. 390, 397 (1887), with Hellreigel v. Manning, 97 N. Y. 56, 61 (1884). And see Note (1935) 48 HARv. L. Rev. 821.

152. As in Paine v. Meller, 6 Ves. 349 (Ch. 1801); Rhomberg v. Zapf, 201 Iowa 928, 208 N. W. 276 (1926); McGinley v. Forrest, 107 Neb. 309, 186 N. W. 74 (1921); Appleton Electric Co. v. Rogers, 200 Wis. 331, 228 N. W. 505 (1930).

153. As in Neponsit Realty Co. v. Judge, 106 Misc. 445, 176 N. Y. Supp. 133 (Sup. Ct. 1919); Amundson v. Severson, 41 S. D. 377,170 N. W. 633 (1919).

154. As in Pellegrino v. Giuliani, 118 Misc. 329, 193 N. Y. Supp. 258 (Sup. Ct. 1922).

155. As in Libman v. Levenson, 236 Mass. 221, 128 N. E. 13 (1920).

156. Cf. Amundson v. Severson, 41 S. D. 377,170 N. W. 633 (1919) (all but 30 acres of 120 acre tract washed away by Missouri River).

157. E.g., Summers v. Midland Co., 167 Minn. 453, 209 N. W. 323 (1926); Relfo v. Osmers, 252 N. Y. 320,169 N. E. 399 (1929).

158. As in Combs v. Fisher, 3 Bibb 51 (Ky. 1813); Rhomberg v. Zapf, 201 Iowa 928, 208 N. W. 276 (1926), discussed in Note (1927) 12 IowA L. REv. 179.

159. As in Pellegrino v. Giuliani, 118 Misc. 329, 193 N. Y. Supp. 258 (Sup. Ct. 1922) (express provision as to loss by fire held inapplicable to loss by windstorm). 
American forms of real estate contracts frequently contain provisions specifically dealing with the matter, at least to some extent. ${ }^{100}$ Such an agreement, moreover, does not prevent equitable conversion for other purposes. Often, however, there is no such specific provision. Sales of real estate may be made upon open contracts; ${ }^{\mathbf{1 0 1}}$ and, even in formal contracts, it may be that no clause as to burden of loss is included. The law must then allocate the loss in the event that one occurs. Up to the present time, this problem of allocation has been dealt with by the courts without statutory aid; and, in order to appraise any proposals for legislative action such as will presently be discussed, a somewhat detailed examination of the manner in which the law has been developed by the courts without legislative assistance is necessary.

At least five different views as to the allocation of the burden of fortuitous losses as between vendor and purchaser have been advanced, and at least three of these have substantial support in the cases. ${ }^{162}$ (1) The view most widely accepted is that first enunciated in Paine v. Meller, ${ }^{163}$ that from the time the vendor-purchaser relation arises the burden of loss is on the purchaser ${ }^{104}$ even though the vendor may be in possession. ${ }^{165}$ This view applies with strict logic the theory of equitable

160. See, e.g., the form of real estate contract prepared by the Mfetropolitan Title Guaranty Company, said to be "about the most comprehensive one in use in New York City." Handier, Cases on Vendor and Purchaser (1933) 83. The provision of this form as to burden of loss is: "The risk of loss or damage . . . by fire until delivery of the deed is assumed by the seller." Id. at 86. There is no similar provision in the form of real estate contract most commonly used in England, viz. THE Law Socrery's Co:idrrons of SALE (1934).

161. An open contract is "a contract simply ascertaining the parties, the property to be sold and the price, and leaving the other terms to be implied by law." 1 Wrrmuss, VENDOR AND PURChaser (3d ed. 1922) 16.

162. No attempt is here made to classify in detail the decisions in the various states. The cases are collected in Notes (1923) 22 A. L. R. 575; (1926) 41 A. L. R. 1272; (1927) 46 A. L. R. 1126. Subsequent decisions are: Ford v. Russell, 13 La. App. 390, 128 So. 310 (1930); Durham v. McCready, 129 Me. 279, 151 Atl. 544 (1930), (1930) 79 U. or PA. L. Rev. 239; Standard Oil Co. v. Dye, 223 MF. App. 926, 20 S. W. (2d) 946 (1929); Persico v. Guernsey, 129 Misc. 190, 220 N. Y. Supp. 689 (Sup. Ct. 1927), affd without opinion, 222 App. Div. 719, 225 N. Y. Supp. 890 (4th Dep't, 1927), 228 App. Div. 850, 239 N. Y. Supp. 925 (4th Dep't, 1930); Oak Bldg. \& Roofing Co. v. Susor, 32 Obio App. 66, 166 N. E. 903 (1929). There is a good analysis of the state of the authorities in Note (1931) 29 Mircr. L. Rev. 487. As to the English law, see Fry, Sppcric Perforzacice of Co:itracts (6th ed. 1921) $\S \$ 909-917 ; 1$ Dart, Vemoons AND Purcenasers (8th ed. 1929) 269 et seq.

163. 6 Ves. 349 (Ch. 1801).

164. See Keener, The Burden of Loss as an Incident of the Rigltt to the Sfecific Performance of a Contract (1901) 1 CoL. L. Rev. 1; 5 Pontrox, EQuntr Jonisfruderice (2d ed. 1919) § 2282; Pound, Progress of the Law, 191S-1919-Equily (1920) 33 Hirs. L. REv. 813,826 et seq.

165. Brewer v. Herbert, 30 MI. 301 (1868); Reife v. Osmers, 252 N. Y. 320, 324, 169 N. E. 399, 400 (1929); Dunn v. Yakish, 10 Okla. 388, 61 Pac. 926 (1900); Alaudru v. Humphreys, 83 W. Va. 307, 311, 9S S. E. 259, 261 (1919); 1 A2rrs, CasEs It Eourry JuRISDiction (1901) 236, n. 1; Pound, supra note 164, at 826, n. 68. 
conversion, holding the purchaser to have "become in equity the owner of the premises" so that "they are his to all intents and purposes." (2) A strong minority of American jurisdictions, following an early decision in Massachusetts, ${ }^{167}$ hold that the burden of loss is on the vendor until legal title is conveyed, ${ }^{108}$ although the purchaser is in possession. ${ }^{100}$ These decisions proceed on the basis of common law ideas as to failure of consideration and implied conditions, and disregard the theory of equitable conversion. ${ }^{170}$ (3) It has been urged that the burden of loss should be on the vendor until the time agreed upon for the conveyance of legal title, and thereafter on the purchaser unless the vendor is then in such default as to be unable specifically to enforce the contract; ${ }^{171}$ but this proposed solution of the problem has not been recognized in the decisions. (4) It has been powerfully argued, ${ }^{172}$ and some courts have held, ${ }^{173}$ that the burden of loss should be on the party in possession, whether vendor or purchaser. The theory behind this solution of the problem is that the purchaser in possession is substantial owner of the property and should bear the burdens of ownership, while the purchaser out of possession is not substantial owner; this argument is supported by the decisions which make the right to rents and profits ${ }^{174}$ and the liability for $\operatorname{taxes}^{175}$ and other outgoings ${ }^{176}$ depend upon possession. ${ }^{177}$

166. Lord Eldon, L. C., in Paine v. Meller, 6 Ves. 349, 352 (Ch. 1801).

167. Thompson v. Gould, 37 Mass. 134 (1838). This case involved an action at law by the purchaser under an oral contract to recover a deposit, so that the actual decision is consistent with the majority rule. Cf. Blew v. McClelland, 29 Mo, 304 (1860). But there was a considered dictum to the effect that the same result would have been reached in equity if the contract had been in writing, and the later Massachusetts cases have adopted this view. See especially Libman v. Levenson, 236 Mass. 221, 128 N. E. 13 (1920).

168. See Note (1912) 12 CoL. L. Rev. 257; Griffin, Risk of Loss in Execulory Land Conttracts (1929) 4 NOTRE DAAIE LAWY. 506.

169. La Chance v. Brown, 41 Cal. App. 500, 183 Pac. 216 (1919); Wilson v. Clark, 60 N. H. 352 (1880).

170. But cf. Stone, Equitable Conversion by Contract (1913) 13 Cor. L. REv, 369, 385 et seq., in which the minority American view is supported on equitable grounds.

171. Langdell, A Bries Survey of Equity Jurisdiction (2d ed. 1908) 58 et seq.

172. Williston, The Risk of Loss after an Executory Contract of Sale in the Common Law (1895) 9 Harv. L. Rev. 106, 111, et seq.; 2 Wiruiston, Contracts (1920) $\$ \$ 927$ 953. See also Note (1922) 6 MrNv. L. Rev. 513; (1923) 2 Wrs. L. REv. 174.

173. E.g., Appleton Electric Co. v. Rogers, 200 Wis. 331, 228 N. W. 505 (1930), (1930) 14 MarQ. L. Rev. 183, (1930) 5 Wis. L. Rev. 503.

174. Clark v. Richfield Oil Co., 127 Cal. App. 495, 16 P. (2d) 162 (1932); Iowa Rr. Land Co. v. Boyle, 154 Iowa 249, 134 N. W. 590 (1912); Tucker v. McLaughlin-Farrar Co., 36 Okla. 321, 129 Pac. 5 (1912).

175. National Bank of Athens v. Danforth, $80 \mathrm{Ga} .55,64,7$ S. E. 546, 551 (1887); Miller v. Corey, 15 Iowa 106, 129 Pac. 5 (1863); Millville Aerie v. Weatherby, 82 N. J. Eq. 455, 88 Atl. 847 (1913); Densmore v. Haggerty, 59 Pa. 189 (1868). For a full collection of the decisions as to all aspects of the question of liability for taxes as between vendor and purchaser, see Note (1921) 12 A. L. R. 411.

176. But cf. King v. Ruckman, 24 N. J. Eq. 556, 566 (1873).

177. It is not wholly clear whether the courts and legal writers adopting the posscssion 
Moreover, the practical argument is made that placing the burden of loss on the party in possession will put pressure on him to protect the property. This seems a substantial argument. To be sure, the burden of a loss due to provable negligence falls on the negligent party regardless of which solution of the problem of the burden of accidental loss be adopted; ${ }^{178}$ but it is one thing to say that the party out of possession may escape the burden of loss by proving affirmatively that the loss was due to the other party's negligence, and another to place the burden of loss on the party in possession regardless of negligence on his part. (5) Certain recent legal writers ${ }^{179}$ argue that the burden of loss should be placed on the vendor unless there is something in the contract or in the relation of the parties from which the court can infer a different intention. On this theory, possession "might or might not be a sufficient controlling element."180 There has not as yet been any avowed judicial acceptance of this rather vague test, although it is not inconsistent with most of the decisions in the states adopting the view that the burden of loss is on the vendor until conveyance or with those in the states adopting the possession test.

Where the burden of loss is on the purchaser, ${ }^{181}$ the vendor may enforce specific performance of the purchaser's obligation to pay the purchase price, ${ }^{182}$ while the purchaser cannot recover his deposit or any partial payments he has made. ${ }^{183}$ But the contract is not avoided, and the vendor cannot refuse to convey upon payment of the agreed price. ${ }^{18 \mathrm{t}}$ These consequences follow logically from the conception that the purchaser is in equity owner of the land from the time of the contract or of his possession thereunder, whichever the rule adopted by the par-

criterion for the allocation of the burden of loss refer to actual possession or to the right to possession. Suppose, for example, that possession is to be given when the contract is made and the vendor moves out, but the purchaser does not take possession. If the rationale of the possession test is that which has been here suggested, it would seem that the burden of any loss under such circumstances should fall on the purchaser. Cf. Good v. Jarrard, 93 S. C. $229,238,76$ S. E. 698,701 (1912). Of course, if the vendor wrongiully bept the purchaser out of possession, the result would be otherwise. Cf. Mitchell v. MIutch, 189 Iowa 1150, 179 N. W. 440 (1920).

178. See Mackey v. Bowles, 98 Ga. 730, 734, 25 S. E. 834, 836 (1S96); Note (1923) 22 A. L. R. 575, 583 (loss due to negligence of vendor).

179. Vanneman, Risk of Loss, in Equity, between the Date of Contract to Sell Real Estate and Transfer of Title (1924) 8 Mon. L. REv. 127; Note (1920) 6 Cons. L. Q. 111;

(1930) 79 U. of PA. L. Rev. 239.

180. Vanneman, supra note 179 , at 143.

181. Either because the vendor-purchaser relation has arisen (the majority view) or because the purchaser is in possession (Williston's theory).

182. E.g., Paine v. Meller, 6 Ves. 349 (Ch. 1801).

183. E.g., Pellegrino v. Guiliani, 118 Misc. 329, 193 N. Y. Supp 288 (Sup. Ct. 1922). Prior to legislation allowing equitable defenses in legal actions, a contrary result would have been reached at law; but equity would have enjoined the action at law.

184. A purchaser might well desire to enforce specific performance in spite of the loss if the market value of the land had risen substantially. 
ticular court may be. Where the burden of loss is on the vendor under the Massachusetts rule, he is not entitled to specific performance against the purchaser for the purchase price if there has been substantial ${ }^{185}$ accidental damage to the premises, ${ }^{186}$ and the purchaser can recover his deposit and any partial payments. ${ }^{187}$ It may be, however, that the purchaser desires specifically to enforce the contract with compensation for the damage. The Massachusetts court in Hawkes v. Kehoe $e^{188}$ indicated that the purchaser would not be entitled to such relief, ${ }^{180}$ since "the contract is to be construed as subject to the implied condition that it no longer shall be binding if, before the time for the conveyance to be made, the buildings are destroyed. ..."100 This is a complete rejection of the conception that the purchaser has a property interest in the premises, and, while consistent with the Massachusetts rule as to risk of loss, is open to the serious objection that it gives the vendor an option to avoid the contract which it is doubtful that the parties intended to give him. It would logically follow, moreover, that the vendor could refuse to convey in such a case even though the purchaser tendered the full purchase price. ${ }^{191}$ It would seem, therefore, that specific performance with compensation to the purchaser should be allowed, even in those jurisdictions which place the burden of loss on the vendor until conveyance, ${ }^{102}$ provided that the usual requirements for partial performance with compensation are met. Where the possession test is adopted and the burden of loss is on the vendor because possession has not yet been taken by the purchaser ${ }^{103}$ or where the "risk of loss"104 is on the vendor

185. If the damage is not substantial, the vendor may be able to enforce specific performance with compensation to the purchaser for the damage, as in Capital Savings \& Loan Ass'n v. Convey, 175 Wash. 224, 27 P. (2d) 136 (1933). Cf. Bautz v. Kuhworth, 1 Mont. 133, 135 (1869).

186. E.g., Libman v. Levenson, 236 Mass. 221,128 N. E. 13 (1920).

187. E.g., Wilson v. Clark, 60 N. H. 352 (1880).

188. 193 Mass. 419,79 N. E. 766 (1907).

189. The actual decision in Hawkes $v$. Kehoe was that the purchaser could not recover damages from the vendor for his failure to perform under such circumstances.

190. Hawkes v. Kehoe, 193 Mass. 419, 425, 79 N. E. 766, 767 (1907).

191. In Hallett v. Parker, 68 N. H. 598, 39 Atl. 433 (1896), a purchaser who had pald the purchase price in full was granted specific performance although the buildings on the land had been destroyed by fire subsequent to the making of the contract. Cf. Wilson v. Clark, 60 N. H. 352 (1880), holding that under such circumstances the purchaser can recover partial payments made prior to the loss. It seems very doubtful whether even the Massachusetts court would follow the theory of Hawkes v. Kehoe to the logical extreme of denying specific relief to a purchaser who offered to pay the full price regardless of the loss.

192. See the comment on Hawkes v. Kehoe in Note (1907) 10 L. R. A. (N. S.) 125.

193. As in Phinizy v. Guernsey, 111 Ga. 346, 36 S. E. 796 (1900).

194. Cf. the form of real estate contract quoted supra note 160. 
by express contract stipulation, ${ }^{195}$ this conclusion is even more clearly indicated. ${ }^{196}$ It has been held ${ }^{197}$ that partial performance with compensation will be denied the purchaser where "it can not be ... said ... that the parties would have contracted for the remnant of the property, with an abatement of purchase price, had they anticipated ... [the] loss," since in such cases the loss "sustained is [not] capable of computation" and to grant such relief would be "to make for the parties a new contract-one not contemplated in their original negotiations." This view seems unsound. It is true that partial specific performance with compensation will be denied where the amount of compensation cannot be fairly assessed, ${ }^{199}$ but there seems no substantial dificulty in determining the amount to be abated from the purchase price in respect of physical damage to the premises. ${ }^{200}$ The suggestion that equity will not make over the contract seems beside the point; whatever may be said as to the basis of the doctrine of partial performance with compensation in other cases, ${ }^{201}$ what equity is doing when it grants such relief after an injury to the property while at the risk of the vendor is simply allowing specific relief so far as possible, with damages in the same suit for the vendor's failure to perform completely..$^{202}$

Any practical consideration of the problem of burden of loss as between vendor and purchaser must take account of the matter of insurance. Most cases of damage to real property contracted to be sold involve fire

195. As in Polisiuk v. Mayers, 205 App. Div. 573, 200 N. Y. Supp. 97 (2d Dep't, 1923), leave to appeal denied, 206 App. Div. 765 (2d Dep't, 1923). This would appear to be the rule even in Massachusetts. Allyn v. Allyn, 154 Mass. 570, 28 N. E. 779 (1891); Hawhes v. Kehoe, 193 Mass. 419, 425, 79 N. E. 766, 767 (1907); cf. Kares v. Covell, 180 MInss. 205, 208, 62 N. E. 244,245 (1902).

196. This result has also been reached where the burden of loss is on the vendor beenuce he has not yet perfected title. Eppstein v. Kuhn, $225 \mathrm{MI} .115,125,80$ N. E. 80, 83 (1907).

197. Wheeler v. Gahan, $206 \mathrm{Ky} .366,267$ S. W. 227 (1924). But cf. Godfrey v. Alcom, 215 Ky. 465, 284 S. W. 1094 (1926), (1926) 24 Mice. L. REv. 838, distinguishing Whleeler v. Galtan on what would appear to be the untenable ground that there the purchaser had only an option when the loss occurred. In view of the decision in Godfrey v. Alcom, it may be doubted whether Wheeler $v$. Galsan would now be followed in Kentucky.

198. Wheeler v. Gahan, $205 \mathrm{Ky} .366,371,267$ S. W. 227, 229 (1924).

199. Rudd v. Lascelles, [1900] 1 Ch. 815 ; Brisbane v. Sullivan, 86 N. J. Eq. 411, 99 Atl. 197 (1916).

200. See Phinizy v. Guernsey, 111 Ga. 346, 354, 36 S. E. 796, 799 (1900) (stzting the principles to be applied in determining compensation in such a case). There is less difficulty in assessing compensation here than there is in some other cases where compensation is allowed, as, e.g., Barnes v. Wood, 8 Eq. 424 (1869) (vendor contracting to sell the fee owned only an estate pur autre vie with a possibility of tenancy by the curtey); Moore v. Gariglietti, 228 Ill. 143, 81 N. E. 826 (1907) (vendor owned only undivided twofifths interest); Note (1927) 46 A. L. R. 748, 750 (compensation for inchoate right of dower).

201. Cf. Note (1912) 25 HaRv. L. Rev. 731; Note (1926) 4 TEx. L. REv. 376.

202. Cf. Note (1927) 40 HaRv. L. REv, 476. 
losses $^{203}$ which may be, and ordinarily are, insured against. Decision of where the burden of fire loss shall fall as between vendor and pur* chaser is important in determining both how insurance against fire is to be effected and how insurance money received by a party to the contract is to be distributed. ${ }^{204}$ At least five problems arise in this connection: (1) Has the vendor or purchaser an insurable interest in the premises contracted to be sold? (2) Has the vendor or purchaser an exclusive ownership or interest within the meaning of the usual condition in fire insurance policies requiring the interest of the insured to be that of "unconditional and sole ownership" or the like? (3) Does the making of the contract or possession by the purchaser thereunder bring about such a change of "interest, title or possession" as to avoid insurance theretofore taken out? (4) Is the purchaser entitled to claim insurance money received by the vendor? (5) Can the vendor require the purchaser to apply insurance money received by the latter in payment of the purchase price?

The vendor under a land contract has an insurable interest in the premises regardless of what view is taken as to the burden of loss. If the burden is on him, ${ }^{205}$ he has the same insurable interest as any owner. If the burden is on the purchaser, but the vendor has not been paid in full, he has a security interest in the premises which is clearly insurable; ${ }^{208}$ and even if he has been paid, there is no reason, so far as the doctrine of insurable interest is concerned, why he cannot procure insurance on the property as trustee for the purchaser. ${ }^{207}$ Until the contract is made, the purchaser has, of course, no insurable interest; but once it is made, he can insure his interest ${ }^{208}$ regardless of whether the burden of loss is on him or not. His "equitable title to ... [ [the] property constitutes a good insurable interest therein."209

The New York standard fire policy contains a clause of avoidance "if the interest of the insured be other than unconditional and sole ownership," unless otherwise provided by a written endorsement upon the policy. ${ }^{210}$ This clause does not, of course, affect insurance taken out

203. See, however, notes $153-155$, supra.

204. The same principles would be applicable to other insured losses; and cases involving, e.g., tornado insurance, may well arise.

205. As it is until conveyance on the Massachusetts view or until the purchaser takes possession under the possession test urged by Williston.

206. VANCE, INSURANCE (2d ed. 1930) 128 and n. 44.

207. Cf. [Howard Fire] Insurance Co. v. Chase, 5 Wall. 509, 513 (U. S. 1866); Ricrinrds, INSURANCE (4th ed. 1932) § 26 . It may be necessary, however, for the vendor to discloso the facts in order effectively to insure under these circumstances. Cf. note 216, infra.

208. RTCHARDS, INSURANCE (4th ed. 1932) \& 27, n. 32 (collecting cases).

209. Richards, INSURANCE (4th ed. 1932) 41.

210. Lines $20-23$ of the standard fire insurance policy of New York, reprinted in RICHARDS, INSURANCE (4th ed. 1932) 935. This form of policy is prescribed verbatim in 
by the vendor prior to making the contract of sale, ${ }^{211}$ but it may affect insurance taken out by vendor or purchaser thereafter. The decisions on the effect of the clause are numerous, ${ }^{212}$ and for the most part reach results consistent with the proposition that the party to a land contract upon whom the burden of loss will fall in the event that the premises are damaged by fire is unconditional and sole owner within the meaning of the policy provision. ${ }^{213}$ The party who does not bear the burden of loss, on the other hand, may not insure as unconditional and sole owner. ${ }^{214}$ This result is entirely in accord with the theory of equitable conversion and with the doctrine of insurance law that the interest of the insured, in order to satisfy the unconditional and sole ownership clause, must be such "that the substantial burden of any fire loss will fall exclusively upon him, regardless of the technical character of his title." Un15 Under modern forms of policy, if the insured is "unconditional and sole" owner, it is not necessary that the precise character of his interest be stated.216

some six states, and is followed in substance in many others. As to the old New York: standard form, still in use in several states, see note 216, infru. For the Miassachusetts standard form, used in four states, see Patrerson, Cases on Irsurarice (1932) 792 et seq.

211. The clause applies only to conditions existing when the policy is talien out and not to changes in title thereafter. See Varce, Iwsurarice (2d ed. 1930) 703, n. 70.

212. These decisions to 1929 are collected and ably analyzed in Note (1929) 60 A. L. R. 11.

213. VANCE, Insurance (2d ed. 1930) 708. It is frequently said by courts and textwriters that the purchaser is unconditional and sole owner when he has taken possesion under the contract. But, as pointed out in Note (1929) 60 A. L. R. 11, 21, possession should make no difference unless it affects the allocation of the burden of loss batween the parties to the contract. There appears to be no decision taling a contrary view. As to decisions in Georgia, Illinois and Missouri to the effect that the purchaser does not have "unconditional and sole ownership" unless he has paid the entire purchase price, see Note (1929) 60 A. L. R. 11, 26 et seq. These decisions appear to result from the failure of the courts of those states to apply the theory of equitable conversion by contract unless the purchaser had paid in full, and must be regarded as inconsistent with the principles of classical equity as to when conversion takes place.

214. The actual decisions holding vendors under land contracts not to have "unconditional and sole ownership" all appear to have involved possession by the purchaser. Sae Note (1929) 60 A. L. R. 11, 48. But this should not necesearily be decisive, nor should the fact that the purchaser has or has not paid the purchase price. Cf. note 213, sufra. Decisions like National Fire Ins. Co. v. Three States Lumber Co., 217 III. 115, 75 N. E. 450 (1905), indicating that the vendor is unconditional and sole owner until he has treen paid in full, must be regarded as local singularities.

- 215. RICHARDS, Irsurance (4th ed. 1932) 372.

216. The old (1887) form of Nev York standard fire policy (lines 8-9) contained a clause avoiding the policy "if the interest of the insured in the policy be not truly stated therein." VANCE, InsURance (2d ed. 1930) 707. This old New York form, which is still in use in some seven states, is reprinted in Patterson, CAses on Irsurnuce (1932) 786 et seq. Cf. Wooliver v. Boylston Ins. Co., 104 Mich. 232, 62 N. W. 351 (1895).

Under the present standard New York form (lines 25-26), the policy is avoided, unles 
Where the premises contracted to be sold have been insured by the vendor prior to the making of contract, the question arises whether the contract effects a change of interest, title or possession within the meaning of the clause in the standard policy avoiding the insurance "if any change, other than by the death of" a party, "take place in the interest, title or possession of the subject of insurance (except change of occupants without increase of risk)", ${ }^{217}$ unless otherwise provided by written agreement endorsed upon the policy. If the problem be approached as one of construing the words of the policy according to their natural meaning, it would seem that whether or not a contract of sale or a transfer of possession thereunder avoids insurance previously taken out by the vendor should depend upon whether or not the burden of loss has shifted from vendor to purchaser in consequence of the contract or the transfer of possession. ${ }^{218}$ If the making of the contract shifts the burden of loss, so that the vendor, if he were insuring anew, could no longer properly describe himself as "unconditional and sole" owner, there would seem to be a "change of interest" as a result of the contract. If the taking of possession under the contract shifts the burden of loss, then the contract coupled with the purchaser's possession should have a similar effect. But if the burden of loss remains on the vendor, a taking of possession by the purchaser would seem to fall within the exception as to "change of occupants without increase of hazard." There is, however, another standpoint from which the problem may be approached. As has forcefully been pointed out:

"Valuable buildings are usually insured by many policies. Conveyancing for the most part follows a well established practice. A preliminary or executory contract of sale is exchanged, with part payment by the vendee, and an obligation on both sides to complete at a given date, but only provided, upon examination, the title is found as represented....

Where the contract is silent upon the subject, courts differ as to whether the executory vendee must complete despite the intermediate destruction of the building by fire. But however that issue may be determined, it is obviously of great importance to the public to know at what precise stage of such a transaction numerous subsisting policies of the vendor ought in due course to be cancelled, and new policies taken out, or indorsement made on the old, in favor of the vendee. Convenience seems to demand that whether or not the

otherwise provided by written endorsement, if the subject of the insurance be a bullding on ground not owned by the insured in fee simple. Cf. note 210, supra. A purchaser of the feo simple who is in possession under a contract of purchase is, by the weight of authority, an owner in fee simple within the meaning of this clause. See Note (1929) 60 A. L. R. 11, 15. Here again it would appear that possession is material only in so far as it affects burden of loss.

217. New York standard fire policy, lines 28-31, reprinted in RICuARds, INSURANCE (4th ed. 1932) 935.
218. Vance, Insurance (2d ed. 1930) 719.
219. See note 213 , supra. 
vendee takes out insurance to protect his interest, the subsisting policies of the vendor should continue in full force and effect until the deed of conveyance is delivered and title transferred." 220

Approaching the problem in this manner, and construing the standard policy so as to harmonize "with the exigencies of trade," it may be urged that the vendor's insurance is not avoided by the making of the contract to sell even though the burden of loss shifts to the purchaser when the contract is made, at least so long as the vendor remains unpaid, especially in view of the settled principle that a contract of insurance is to be construed most strongly against the insurer. ${ }^{222}$ But where the purchaser takes possession, there is no compelling commercial necessity for construing the policy so as to avoid the termination of the vendor's insurance, since such a transaction is commonly considered by the parties as a real transfer of interest. The interaction of conflicting doctrines as to burden of loss and conflicting views as to the proper approach to the problem of insurance law presented in this situation has resulted in much confusion in the decisions. The prevailing view is that the making of a contract of sale will not of itself avoid the vendor's insurance under the "change of interest, title or possession" clause, but that such insurance will be avoided if the purchaser takes possession under the contract. $^{223}$ There are, however, decisions that the mere making of the contract avoids the vendor's policies, ${ }^{294}$ and, on the other hand, that even possession by the purchaser under the contract will not have this effect. Uniformity on this important matter can, it would seem, be attained only by appropriate specific modifications of the statutory standard fire policies.

Where a vendor collects insurance money for a loss occurring subsequent to the making of the contract of sale, ${ }^{200}$ the matter of burden of

220. Richards, INSURANCE (4th ed. 1932) 384 (footnotes omitted).

221. Ibid.

222. Id. at 114 et seq.

223. VaNce, Insuraxce (2d ed. 1930) 719; Richards, Irsuruice (4th ed. 1932) § 245; Patterson, Cases on Insurance (1932) 180; Note (1929) to A. L. R. 11, 52 et seq. Cf. Westchester Fire Ins. Co. v. Fitzpatrick, 2 F. (2d) 651,654 (C. C. A. 3d, 1924), where it was held that the making of a contract which expressly provided that the burden of loss should be on the vendor until conveyance did not avoid the rendor's insurance, rhere the purchaser had not taken possession under the contract.

224. Wm. Skinner \& Sons' Ship-Building \& Dry-Dock Co. v. Houghton, 92 IId. 68, 92, 48 Atl. 85, 89 (1900); Manning v. North British \& Mercantile Ins. Co., 123 Mio. App. 456, 99 S. W. 1095 (1907).

225. Budelman v. American Ins. Co, 297 III. 222, 130 N. E. 513 (1921); Garner v. Milwaukee Mechanics' Ins. Co., 73 Kan. 127, 84 Pac. 717 (1906); Trichel v. Home Ins. Co., 155 La. 459, 99 So. 403 (1924).

226. The usual situation is that where the vendor was insured prior to the contract and the loss is paid to him either because his policy is held not to be avoided by the contract 
loss as between the parties to the contract is an important factor in determining how the money so received is to be disposed of. Where the burden of loss is on the vendor, this problem is easily dealt with. The loss is the vendor's, and the indemnity for that loss which he receives from the insurer is likewise his; the purchaser, although he is entitled. to the return of his deposit, or may, if he so elects, be able to enforce partial specific performance with compensation, ${ }^{227}$ has no claim to the insurance money. ${ }^{228}$ Where, however, the burden of loss is on the purchaser, a much more difficult problem is presented. In the leading case of Rayner v. Preston, ${ }^{229}$ the Court of Appeal held, over the vigorous dissent of James, L. J., that the purchaser was not entitled either to claim the insurance money received by the vendor or to have it applied to the repair of the damaged premises, and, in Castellain v. Preston, ${ }^{230}$ that the vendor must refund the insurance money to the insurer, on the theory of subrogation. ${ }^{231}$ From the standpoint of technical insurance law, this result is quite correct. ${ }^{232}$ A contract of fire insurance is a contract of indemnity. It insures, not the property, but the interest of the insured in the property. In the case of the vendor, what is insured is his security interest; if he collect in full from the purchaser, he has

(cf. notes 223-225, supra) or because the insurer does not raise the defense of change of interest. Cf. Wm. Skinner \& Sons' Ship-Building \& Dry-Dock Co. v. Houghton, 92 Md. 68, 97, 48 Atl. 85, 91 (1900).

227. See notes 192-196, supra.

228. Phinizy v. Guernsey, 111 Ga. 346, 349, 36 S. E. 796, 797 (1900). The same result was reached in Brownell v. Board of Education, 239 N. Y. 369,146 N. E. 630 (1925), although on rather confused reasoning, the court discussing the case as if it were one where the burden of loss was on the purchaser and purporting to follow Rayner v. Preston, 18 Ch. D. 1 (1881), infra note 229. In Appleton Electric Co. v. Rogers, 200 Wis. 331, 228 N. W. 505 (1930), (1930) 5 WIs. L. REv. 503, where the insurance money received by the vendor exceeded the contract price, the purchaser, who paid the contract price in full after the loss, was denied relief in a suit to compel payment to him of the insurance money. In so far as this case indicates inferentially that the purchaser would not have been entitled to specific performance with compensation if he had taken appropriate proceedings to that end, it seems supportable only on the theory that the contract involved (for the sale, for $\$ 30,000$, of land worth $\$ 10,000$ and buildings appraised for insurance purposes at $\$ 388,000$, for damage to which $\$ 113,667$ had been collected by the vendor) was so unfair and so improvident on the vendor's part as not to be specifically enforceable at all. Cf. Higgins v. Butter, 78 Me. 520, 7 Atl. 276 (1886); 5 PoMeroy, op. cit. suppra note 164, at $\$ 2211$; Note (1930) 65 A. L. R. 7, 75 et seq. In Phinizy v. Guernsey, supra, specific performance with compensation was granted the purchaser although he was held not to be entitled to insurance money received by the vendor. See also Note (1925) 10 CoRs. L. Q. 379, 381.

229. 18 Ch. D. 1 (1881).

230. 11 Q. B. D. 380 (1883), rev'g 8 Q. B. D. 613 (1882).

231. Cf. Richards, Insurance (4th ed. 1932) § 54; VANCE, Insurance (2d ed. 1930) 669 et seq.; (1930) 5 Wrs. L. Rev. 503, 507 et seq.

232. See Brownell v. Board of Education, 239 N. Y. 369, 374, 146 N. E. 630, 632 (1925); Pound, supra note 164, at 829, n. 78; Richards, Insurance (4th ed. 1932) 69. 
suffered no loss and the insurance company should not be required to pay, while if he collect from the insurer rather than proceed against the purchaser, the insurer is entitled to subrogation to his rights against the purchaser under the contract. Hence, as between vendor, purchaser and insurer, the loss will eventually fall on the purchaser. But this result, although it may be "law," does not at all "savor of layman's views of equity," and disregards "the meaning of the [insurance] transaction in the market place."234 In business practice, the insurance money is thought of as substituted for the insured property; the insurance is regarded as being "on the buildings," not simply on the vendor's security interest in the buildings. Moreover, to allow the insurer to escape paying a fire loss simply because the vendor has agreed to sell the insured property appears, to the layman at least, to give the insurer a wholly unmerited windfall. There has been no uncontemplated change of risk; $;^{235}$ the insurance company is paying exactly the sort of loss it agreed to pay-why should it be allowed to shift the loss it has contracted to bear onto the unfortunate purchaser? ${ }^{230}$ Such arguments as these have prevailed in most American courts to which the question has been presented, ${ }^{237}$ and the purchaser has been allowed the benefit of the vendor's fire insurance where the burden of loss was upon the purchaser at the time of the fire. ${ }^{238}$ In England, moreover, similar arguments have

233. Brownell v. Board of Education, 239 N. Y. 369, 374, 146 N. E. 630, 632 (1925).

234. [Vance] Comment (1924) 34 YALE L. J. 87, 90.

235. Unless the making of the contract amounts to a forbidden "change of interest, title or possession" (cf. notes 223-225, supra), in which event the policy is avoided.

236. On the other hand, it may be argued that the purchaser gets an unmerited nindfall if he is allowed the advantage of insurance which he did not take out and of which he may not even have known.

237. The strongest American authority in accord with Rayner v. Preston is a carefully considered dictum in Brownell v. Board of Education, 239 N. Y. 369, 372, 146 N. E. 630, 631 (1925), (1925) 25 CoL. L. Rev. 477, (1925) 10 Cors. L. Q. 379 . The decision in King v. Preston, $11 \mathrm{La}$. Ann. 95 (1856), can no longer be regarded as authority to that effect. See Automatic Sprinkler Corp. v. Robinson-Slagle Lumber Co., 147 So. 542, 544 (La. App. 1933). But there are intimations in accord with Rayner v. Preston in Fortlander v. Elston, 52 Fed. 180, 185 (C. C. A. 6th, 1892); White v. Gilman, 138 Cal. 375, 71 Pac. 436 (1903) ; Remington v. Sabin, 132 Minn. 372, 157 N. W. 504 (1916); Plimpton v. Farmer's Mutual Fire Ins. Co., 43 Vt. 497 (1871).

238. See Brady v. Welsh, 200 Iowa 44, 204 N. W. 235 (1925), (1925) 11 Iown L. REv. 73, (1925) 35 Yare I. J. 240; Wm. Skinner \& Sons' Ship-Building \& Dry-Docli v. Houghton, 92 Md. 68, 48 Atl. 85 (1900), (1901) 15 Harv. L. Rev. 160; Standard Oil Co. v. Dye, 223 Mo. App. 926, 20 S. W. (2d) 946 (1929), (1930) 7 N. Y. U. L. Q. REv. 754; McGinley v. Forrest, 107 Neb. 309, 186 N. W. 74 (1921); Afilville Aerie v. Weatherby, 82 N. J. Eq. 455, 457, 88 Atl. 847, 848 (1913); Peck v. Hale, 11 Ohio App. 418 (1919); Ruczell v. Elliott, 45 S. D. 184, 186 N. W. 824 (1922); VANCE, Irsuarice (2d ed. 1930) 659 et seq. Some courts have even gone so far as to hold an optionee entitled, upon exercising his option to purchase, to insurance money received by the optionor in respect of a los3 occurring after the option was given. See Dolan v. Spencer, 92 Colo. 389. 21 P. (2d) 411 
resulted in the attempted statutory modification of the rule of Rayner $v$. Preston. The Law of Property Act, 1922, provided that any insurance money becoming payable to the vendor should, unless otherwise provided by the contract of sale, "be held or receivable by the vendor on behalf of the purchaser" and paid by the vendor to the purchaser accordingly. ${ }^{\text {230 }}$ As this provision finally came into force, ${ }^{240}$ however, it has effect only "subject to ... any requisite consents of the insurers";241 and the addition of these innocent-appearing words appears as a practical matter to have nullified the provision almost completely. ${ }^{242}$ Unless the insurer has consented that the purchaser shall have the advantage of the vendor's insurance, the statutory provision does not apply and "the vendor will be entitled, as between himself and the purchaser, to retain the insurance money."243

As between the parties to the contract of sale, the purchaser may be

(1933); Williams v. Lilley, 67 Conn. 50, 34 Atl. 765 (1895); Peoples St. Ry. Co. v. Spencer, 156 Pa. 85, 27 Atl. 113 (1893); Schnee v. Elston, 299 Pa. 100, 149 Atl. 108 (1930), (1930) $78 \mathrm{U}$. of PA. L. Rev. 791. This seems clearly unsound, for two quite independent reasons: (1) Even though there is a binding contract, the purchaser cannot claim insurance monoy received by the vendor where the burden of loss is on the vendor, although the purchaser is entitled to specific performance with compensation for the loss. Phinizy v. Guernsey, $111 \mathrm{Ga} .346,36 \mathrm{~S}$. E. $796(1900)$. Cf. note 228 , supra. (2) In the case of an option, the optionee is not even entitled to specific performance with compensation. Caldwell v. Frazier, 65 Kan. 24, 68 Pac. 1076 (1902); Gamble v. Garlock, 116 Minn. 59, 133 N. W. 175 (1911). The substantial weight of authority does not permit the optionce, by exercising the option, to take advantage of the optionor's insurance. Edwards v. West, 7 Ch. D. 858 (1878); Trumbell v. Bombard, 171 App. Div. 700, 157 N. Y. Supp. 794 (3d Dep't, 1916), aff'd without opinion, 225 N. X. 638, 121 N. E. 895 (1919); Gilbert \& Ives v. Port, 28 Ohio St. 276 (1876); Strong v. Moore, 105 Ore. 12, 24, 207 Pac. 179, 183 (1922); Rice v. Crump, 5 Tenn. Civ. App. 146 (1914); Clark v. Burr, 85 Wis. 649, 55 N. W, 401 (1893). The result may be otherwise if the option contract provides that the optlonce shall have the benefit of the vendor's insurance. See Carnation Lumber \& Shingle Co. v. Tolt Land Co., 103 Wash. 633, 642, 175 Pac. 331, 334 (1918). Some of the declslons which allow the optionee to reach the optionor's insurance money may perhaps be sustained on the theory of an implied contract of this sort.

239. $12 \& 13$ Gro. V., c. 16, § 105 (1922).

240. As $\S 47$ (1) of the Law of Property Acr, 1925, 15 Geo. V., c. 20. (1925). Most of the provisions of the Law of Property Act 1922, including Section 105, never came into actual effect, being superseded, prior to the effective date of the Act, by the English property legislation of 1925. See RAdclIfFE, REAL Property LAw (1933) 202.

241. 15 Gro. V, c. $20, \S 47$ (2) (b) (1925). The securing of such consents "is usually a mere matter of form." Note (1929) 73 SoL. J. 564. But failure to secure them may have very serious consequences. See notes $242-243$, infra.

242. See Note (1927) 164 L. T. 502; Gibson, Conveyancunc (13th ed. 1928) 105 et seq.; Note (1929) 73 Sor. J. 564; Cheshire, Modern Law of Real Property (3d ed. 1933) 647, n. 1.

243. Gibson, Conveyancinc (13th ed. 1928) 106. This has not always been realized by American commentators. See, e.g., (1930) 7 N. Y. U. L. Q. REv. 754, 755. 
given the benefit of the vendor's insurance by agreement. ${ }^{24}$ But if the vendor assigns his policy to the purchaser without the consent of the insurer, it will become void for violation of the clause against assignment before loss; ${ }^{245}$ and if the vendor agrees to give the purchaser the benefit of his insurance but does not assign the policy, he runs the risk of having to repay to the insurer any amount which is paid to the purchaser under this agreement. ${ }^{246}$ These difficulties are eliminated, of course, if the insurer assents to the assignment or agreement.

The purchaser, once the contract is made, has an insurable interest in the property, ${ }^{247}$ and may and frequently does insure. If a loss occurs, any insurance which the purchaser collects under a policy insuring his interest belongs to him free of any claim of the vendor. ${ }^{248}$ Where, however, the purchaser, pursuant to the contract, insures the property with loss payable to vendor and purchaser "as interest may appear," the vendor is entitled to the insurance money to the extent of payments due on the purchase price, ${ }^{249}$ or, if no payments are due, can require such money either to be applied to the restoration of the premises ${ }^{200}$ or held as security for the unpaid portion of the price, ${ }^{251}$ as the purchaser may elect. $^{252}$ This method of insuring, which is that ordinarily employed where the relation of the parties is that of mortgagor and mortgagee, is

244. E.g., Zenor v. Hayes, 228 MII. 626, 81 N. E. 1144 (1907) (assignment of vendor's policy to purchaser).

245. Line 31 of the New York standard fire policy, reprinted in Ricmanns, Irisorarics (4th ed. 1932) 935. As to the construction of this clause, see id. at $\S 248$.

246. Cf. West of England Fire Ins. Co. v. Isaacs, [1897] 1 Q. B. 226; Phoenir Acsurance Co. v. Spooner, [1905] 2 K. B. 753; 1 Dart, Vendors and Purcmasers (6th ed. 1983) 196 et seq., 2 id. at 913 et seq. But see Godfrey v. Alcorn, 215 Ky. 465, 284 S. W. 1094 (1926). 247. See note 20S, supra.

248. Hammer v. Johnson, 44 Ill. 192, 193 (1867); Goodin \& Barney Coal Co. v. Southern Elkhorn Coal Co., 219 Ky. 827, 832, 294 S. W. 792, 794 (1927); Gassaway v. Browning, 175 S. W. 481, 482 (Tex. Civ. App. 1915).

249. Fanning v. Equitable Fire \& Marine Ins. Co., 46 IIl. App. 215 (1892). In Grange Mill Co. v. Western Assurance Co., 118 Ill. 396, 9 N. E. 274 (1896), the same result rras reached where the purchaser had agreed to insure for the vendor's benefit and, after insuring the premises in his own name, became insolvent.

250. Hatch v. Commerce Ins. Co., 216 Iowa 860,249 N. W. 164 (1933), (1933) 19 Iowa L. REv. 129.

251. Scott v. Crinnian, 43 Ont. L. R. 430,433 (1918). Even though the purcbace price be not yet due, the vendor may be entitled to have the insurance money applied thereon, if the contract of sale so provides. Dysart v. Colonial Fire Underwriters, 142 Wash. 601, 609, 254 Pac. 240, 243 (1927).

252. Hatch v. Commerce Ins. Co., 216 Iowa 860,249 N. W. 164 (1933). But cf. Shar v. Cramton, 256 Mich. 293, 295, 239 N. W. 366, 367 (1931). In Naquin v. Texns Savings \& Real Estate Investment Ass'n, 95 Tex. 313, 67 S. W. 85 (1902), where the purchacer had agreed to insure for the vendor's benefit, the vendor was held entitled to apply the insurance money to restoring the damaged premises as against the purchacer's contention that it should be applied on unmatured installments of the purchase price. 
the most satisfactory way of arranging insurance between vendor and purchaser. ${ }^{253}$

A situation having considerable resemblance to that where premises contracted to be sold are damaged by fire and the vendor collects insurance arises where such premises are taken by public authority under the power of eminent domain and the vendor receives compensation for the taking. Unless it be held that the condemnation has rendered the vendor's title unmarketable ${ }^{254}$ or has violated a covenant to convey free of incumbrances, ${ }^{255}$ the loss due to such condemnation is allocable on the same basis as a loss due to fire or other casualty. If the burden of loss is on the purchaser either from the time the contract was made or because he has taken possession, he cannot recover his payments and may be compelled to pay the full contract price although part ${ }^{206}$ or all ${ }^{267}$ of the property has been taken by eminent domain. But there is no such difficulty as is encountered in the insurance cases in regarding the compensation paid by public authority as taking the place of the condemned property. ${ }^{268}$ The purchaser is entitled to the compensation received by the vendor, ${ }^{259}$ but the vendor may hold that compensation as security for the payment by the purchaser of the contract price. ${ }^{260}$ If the amount paid as compensation exceeds the purchase price, the purchaser profits; ${ }^{261}$ while if the entire property. is condemned for less than the contract price, the loss falls upon him. ${ }^{262}$ On the other hand, if it be held that the burden of loss is on the vendor at the time of the condemnation,

253. See Pound, supra note 164, at 828; Richards, Insurance (4th ed. 1932) 341, n. 92. Cf. 2 WIILISTON, Contracts (1920) 1790 et seq.

254. As in Miller v. Calvin Phillips \& Co., 44 Wash. 226, 87 Pac. 264 (1906). The pendency of condemnation proceedings at the time the contract is made may render the vendor's title unmarketable. Cavenaugh v. McLaughlin, 38 Minn. 83, 35 N. W. 576 (1887). Cf. Note (1930) 67 A. L. R. 1104.

255. As in Kares v. Covell, 180 Mass. 206, 62 N. E. 244 (1902); Johnston v. Callery, 173 Pa. 129, 33 Atl. 1036 (1896). See also Sanborn, J., dissenting, in Nixon v. Marr, 190 Fed. 913,919 (C. C. A. 8th, 1911).

256. Nixon v. Marr, 190 Fed. 913 (C. C. A. 8th, 1911), (1912) 12 Cor. L. REv، 257 ; Kuhn v. Freeman, 15 Kan. 423 (1875); Summers v. Midland Co., 167 Minn. 453, 209 N. W. 323 (1926), (1927) 25 Mich. L. Rev. 297; Reife v. Osmers, 252 N. Y. 320,169 N. E. 399 (1929), (1930) 39 YaLE L. J. 916.

257. Gammon v. Blaisdell, 45 Kan. 221, 25 Pac. 580 (1891).

258. Cf. Cullen \& Vaughn Co. v. Bender Co., 122 Ohio St. 82, 90, 170 N. E. 633, 635 (1930).

259. Nixon v. Marr, 190 Fed. 913, 917 (C. C. A. 8th, 1911); Stevenson v. Loehr, 57 III. 509, 511 (1871) ; Summers v. Midland Co., 167 Minn. 453, 456, 209 N. W. 323, 324 (1927) ; Reife v. Osmers, 252 N. Y. 320, 324, 169 N. E. 399, 400 (1929).

260. Stevenson v. Loehr, 57 Ill. 509, 511 (1871); Summers v. Midland Co., 167 Minn. $453,456,209$ N. W. 323, 324 (1927).

261. As in Stevenson v. Loehr, 57 Ill. 509, 512 (1871).

262. As in Gammon v. Blaisdell, 45 Kan. 221, 25 Pac. 580 (1891). 
the purchaser need not complete ${ }^{203}$ and the vendor is entitled to retain the compensation..$^{24}$ If the purchaser is entitled to partial specific performance with an abatement of the purchase price, it would seem that the amount of that abatement would not necessarily be the same as the amount of the compensation the vendor has received in the condemnation proceedings. ${ }^{205}$

Aside from the rather abortive English legislation with respect to insurance as between vendor and purchaser and the indirect effect of American statutes prescribing standard forms of insurance policies, the law as to the burden of loss under land contracts and as to the practically related problems of fire insurance upon (and compensation on condemnation of) the property contracted to be sold has developed up to the present time without legislative aid or hindrance. Recently, however, the attention of the National Conference of Commissioners on Uniform State Laws has been directed to these matters. At the recent fortyfourth annual meeting of the Conference, August 21 to 27, 1934,, there was submitted ${ }^{267}$ the first tentative draft of a proposed Uniform Vendor and Purchaser Risk Act. ${ }^{2 e s}$ This proposed Act provides:

"Any contract hereafter made in this state for the purchase and sale of realty shall be interpreted as imposing upon the parties the following rights and duties, unless the contract expressly provides otherwise:

"(a) If before transfer of the legal title, or of the possession of the subject matter of the contract, all or a material part thereof is accidentally destroyed or is taken by eminent domain, the vendor cannot enforce the contract, and the purchaser is entitled to recover any portion of the price that he has paid.

"(b) If after the transfer of the legal title, or of the possession of the subject matter of the contract, all or any part thereof is accidentally destroyed or is taken by eminent domain, the purchaser is not thereby relieved from a duty to pay the price or entitled to recover any portion thereof that he has paid.

"(c) Where a vendor receives compensation from insurance or otherwise for

263. Ogren v. Inner Harbor Land Co., S3 Cal. App. 197, 256 Pac. 607 (1927); Kures v. Covell, 180 Mass. 206, 62 N. E. 244 (1902); Note (1912) 12 Cor. L. REv. 257.

264. But where the condemnation proceedings were pending when the contract was made and no express provision is made in the contract for the disposition of companeation awarded in those proceedings, the purchaser is entitled to the compensation awarded. Security Co. v. Rice, 215 Cal. 263, 9 P. (2d) 817 (1932); Note (1933) 82 A. L. R. 1053.

265. Cf. note 238, supra. But see Cullen \& Vaughn Co. v. Bender Co., 122 Ohio St. $82,94,170$ N. E. 633,637 (1930), where it is said that an optionee is entitled, upon exercise of an option of purchase, to the compensation received by the optionor from the condemnor in respect of the taking by eminent domain proceedings of part of the optioned property.

266. At Milwaukee, Wisconsin.

267. By Professor Samuel Williston.

268. The Act was originally proposed as the "Uniform Vendor and Purchacer Act." This was amended by the Conference in Committee of the Whole to "Uniform Vendar and Purchaser Risk Act." 
such destruction or taking, the purchaser shall be entitled to enforce the contract with an abatement of the price to the extent of such compensation.

"(d) Where a purchaser receives compensation from insurance or otherwise or such destruction or taking, the vendor shall be entitled either to have such compensation applied to the payment of the price to the extent that is necessary or, at the option of the purchaser, applied to the restoration of the subject matter."209

The proposed Act, it will be noted, proceeds on the theory that the allocation of burden of loss and the distribution of insurance money or compensation upon condemnation between vendor and purchaser is a matter of contract between the parties, and enacts a rebuttable statutory presumption applicable to all contracts made in the state. In the course of consideration of the draft by the Conference, an attempt was made to amend the proposed Act so as to apply not only to contracts made in the state but also to contracts for the sale of land situated in the state..$^{270}$ This amendment was rejected, largely because it was thought to raise difficult questions of conflict of laws. Certainly an attempt to base the proposed statute on two divergent theories, (1) that it enacts a rule of interpretation applicable to all contracts made within the state, (2) that it enacts a rule of property applicable to all contracts as to land within the state unless the parties contract themselves out of the rule, would be highly anomalous. So far as the question of burden of loss is concerned, much may be said in favor of the latter theory. Most lawyers probably think of the rule as to "risk of loss" established by the decisions in any jurisdiction as a rule of property law which may be abrogated by express contract ${ }^{271}$ rather than as a rule as to the interpretation of land contracts. Certainly those jurisdictions which place the burden of loss on the purchaser have proceeded on a property theory rather than on the basis of implying a term in the contract which the parties have failed to supply. If this view be taken regarding the nature of the rule, it seems more logical to change the rule of property than to set up a statutory presumption that the parties have contracted that the rule shall not apply unless they expressly agree that it shall. On the other hand, it seems difficult to deal with the distribution of insurance money except on a contract theory, and the same may be said of the disposition of compensation for the condemnation of property contracted to be sold.

269. Section 1, reprinted here, is the operative part of the Act. The remaining sections are formal (short title, interpretation, effective date, etc). The text of Section 1 of the Act as reprinted is taken from the mimeographed transcript of the proceedings of the Conference sitting in Committee of the Whole on the consideration of the Act.

270. This amendment was proposed by Commissioner Karl N. Llewellyn.

271. Compare the "rules for ascertaining the intention of the partics" as to transfer of title to chattels which prevail under the SALES ACT, § 19, 1 U. L. A. (1931) 147, "unless a different intention appears." 
The paragraphs of the proposed Act which deal with burden of loss adopt the possession test advocated by Williston. ${ }^{272}$ The discussion of these paragraphs by the Conference did not concern itself with the relative merits of the various bases for the allocation of that burden which courts have adopted and legal writers have argued for, but was confined to minutiae of drafting. ${ }^{273}$ The desirability of the substantive change which the Act would make in the law of most of the states was taken for granted rather than consciously demonstrated. Even though it be granted arguendo that the change should appeal to all by reason of its inherent reasonableness, ${ }^{274}$ it may be doubted whether the Conference will not have to make more articulate its reasons for proposing so sweeping a change in the law of most American jurisdictions if it is to hope for general adoption of its proposal by the various state legislatures. A change of similarly sweeping character was proposed in the case of the Uniform Written Obligations Act ${ }^{275}$ with but indifferent success.20 Unless the Conference and the other proponents of the Uniform Vendor and Purchaser Risk Act take further steps affirmatively to demonstrate the desirability of the rather radical change proposed, that Act may suffer a similar fate.

The provisions of the proposed Act as to the disposition of insurance received by the parties to a land contract have the effect of adjusting matters inter partes in substantially the same way as they would be adjusted if the contract had provided for insurance "as interest may appear."277 If insurance is paid to the vendor, the purchaser gets the advantage of the insurance by way of abatement of the purchase price. ${ }^{273}$ If insurance is paid to the purchaser, the vendor's security interest is

272. See notes 172 and 173 , supra.

273. Thus, the Conference discussed deleting "expressly" from the first paragraph of the proposed Act; substituting a broader term which would include chattels real for the term "realty" in that paragraph; substituting "without fault of either party" or "without fault of the purchaser" for "accidentally" in paragraphs (a) and (b); clarifying the language of paragraphs (a) and (b) as to when the burden of loss shifts from vendor to purchaser; etc.

274. But cf. Pound, supra note 164, at 826, n. 68; Note (1931) 29 MLrer. L. REv. 487, 489 et seq.

275. Recommended by the Conference in 1925. See Hardozoor of THE Natro:iar Confrrence of Cosminsioners on Unirorar State Laws (1925) 193-215, 305-316.

276. Up to 1933, this Act had been adopted in only two states-Pennsylvania and Utah. Hardoook of the Nationar Conference of Cosamssioners oi Umirozur State Lims (1933) 518.

277. Cf. note 253 , supra.

278. The enactment of this provision would abolish the rule of Rayner $v$. Preston in the small number of American jurisdictions where it appears to be accepted. Cf. note 237, supra. There might, however, be difficulty because of the insurer's poscible claim to subrogation. Cf. notes 231,246 , supro. 
protected by the requirement that the insurance money be applied on the unpaid purchase price or used in the restoration of the premises. ${ }^{270}$ The Act thus proposes to do for all vendors and purchasers who do not contract themselves out of it what most well-advised vendors and purchasers now do for themselves by express contract. The problem of distributing condemnation awards is handled in much the same way as it has been handled by the courts without statutory guidance. ${ }^{280}$

It will be observed that the proposed Act does not purport to deal with the rights and liabilities of the insurer. Upon consideration of the Act by the Conference, an amendment was proposed ${ }^{281}$ which provided, in substance, that where the vendor had insured prior to the making of the contract of sale, such insurance should continue in favor of the vendor ${ }^{282}$ until expressly cancelled ${ }^{283}$ or unless transferred to the purchaser, ${ }^{284}$ and that, where the vendor received insurance money and the purchase price of the property was abated accordingly, the insurer should not be subrogated to the vendor's rights against the purchaser. ${ }^{285}$ It was urged that such a provision was desirable to protect small purchasers who took possession under usual forms of installment contracts and who did not themselves insure. Considerable opposition to this amendment developed, based principally on two grounds: (1) That it would raise serious difficulties if applied, as it would have to be applied in order to be of practical value, to policies in foreign insurance companies and to policies written outside the state; (2) that an Act containing a provision which modified statutory standard forms of insurance policies would have little chance of adoption by the several state legislatures. ${ }^{280}$ The

279. Cf. notes 249-252, supra.

280. Cf. notes 259-264, supra.

281. By Commissioner Llewellyn.

282. Subject, of course, to the provisions of the proposed Act as to the distribution of the proceeds of such insurance between vendor and purchaser in the event of loss.

283. This would do away with the avoidance of insurance for "change of interest, right or title" as a result of the contract of sale or possession thereunder. Cf. notes 217-225, supra.

284. If so transferred, insurance money received by the purchaser in the event of loss would, unless otherwise agreed by the parties to the land contract, be distributed in accordance with the provisions of the proposed Act.

285. Cf. notes 231,246 , supra.

286. In discussing the proposed amendment, Commissioner E. E. Brossard, Chairman of the Legislative Drafting Committee of the Conference, said: "If this Act invades the insurance field, it means that it will be adopted in almost no states at all. The standard fire insurance policy of New York is in force in almost every jurisdiction in the United States, and that standard policy in the law contradicts what we propose to say here; and if you introduce this in the Legislature, the Insurance Commission of the state will procecd to kill the bill. You are invading a field that means as a practical matter you can't get this adopted in the states, and there is no use of calling it 'an Act to make uniform 'a law in the various states' if you can't pass it anywhere. It would be going afield to meet disaster." 
amendment was finally withdrawn; but the substance of the proposal appears worthy of further consideration. Such a statutory provision, if generally adopted, would eliminate the unfortunate lack of uniformity in the law as to the effect of a contract for the sale of land or possession thereunder upon the continued validity of the vendor's insurance policies, ${ }^{28 \pi}$ and would obviate a difficulty which might otherwise arise from the provision of the proposed Act that the purchaser shall be entitled to have the vendor's insurance applied upon the unpaid purchase price. ${ }^{2: 3}$ Since, however, the question involved is primarily one of insurance law, it would seem that it could best be dealt with by a uniform amendment to the standard fire policy statutes. Perhaps such an amendment might, with the concurrence of the National Convention of Insurance Commissioners, be proposed along with, but independently of, the contemplated Vendor and Purchaser Risk Act.

The Conference, after considering the proposed Act in Committee of the Whole, decided that the matter should go over until its next meeting, to be held beginning July 9, 1935. Prior to that meeting, the first tentative draft of the Act is being considered by the Real Property Section of the Conference as well as by the Commercial Acts Section which originally proposed it. A revised draft, which will embody changes made to meet minor objections to the Act as originally proposed, ${ }^{259}$ will be submitted at the next meeting of the Conference, and action may perhaps be taken by the Conference at that time. If a Uniform Vendor and Purchaser Risk Act in substantially the form of the tentative draft is recommended by the Conference and generally adopted by the states, it will result in the most general and thoroughgoing single change in the law of equitable conversion by contract which has yet been made by legislative action.

\section{$\mathrm{V}$}

\section{Forfeitures Under Installament Contracts}

The many and difficult problems raised by installment land contracts where time is expressly made of the essence ${ }^{200}$ are for the most part outside the scope of this discussion; ${ }^{291}$ but there is one matter involving

287. Cf. notes $217-225,283$, supra.

288. Cf. note 285 , supra.

289. Cf. note 273 , stpro.

290. The suggestion of Lord Thurlow in Willizms v. Thompson (Ch. 1782), stated in Newland, Contracts withm the Junssiction of Courts of Equrty (1821) 238, and Gregson v. Riddle (Ch. 1784), stated id. at 239, that time cannot be made of the eszence of a land contract in equity even by express provision, has long since been repudiated. See Seton v. Slade, 7 Ves. 265, 270 (Ch. 1802); 2 Wurrstor, Cosirncrs (1920) 1632.

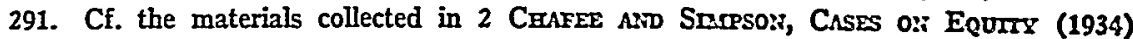
1235-1258. 
the doctrine of equitable conversion as applied to such contracts and legislation with regard to them which it seems appropriate to consider. This matter is, moreover, of large practical importance, especially in view of the increasing tendency in many parts of the United States to arrange the financing of land purchases on the basis of installment contracts rather than on the basis of purchase-money mortgages. ${ }^{202}$

Whether the doctrine of equitable conversion is applicable to contracts for the sale of land where time has expressly been made of the essence is a disputed question on the authorities. Some courts have said that in such a case there is a condition precedent to the vendor-purchaser relation, so that the purchaser cannot be regarded as equitable owner so long as any part of the purchase money remains unpaid. ${ }^{203}$ It seems preferable, however, to say that there is a mutually specifically enforceable contract from the beginning, subject to a condition of prompt payment of future installments which, if given effect by the courts, will put an end to the vendor-purchaser relation immediately upon default by the purchaser and thus divest his equitable ownership. 204 It should be immaterial, so far as equitable conversion is concerned, that the contract in terms provides that prompt payment of each installment of the purchase price shall be a "condition precedent" to any rights under the contract, and contains a forfeiture clause. The condition of prompt payment is one which operates to divest a relationship between the parties which has in fact arisen by virtue of the contract. Calling it a "condition precedent" does not require the courts to enforce it as such. ${ }^{200}$ What is really involved here is an attempt to induce the courts, by the use of emphatic language, to enforce a forfeiture provision. This attempt equity, looking at the substance of the transaction, should disregard.

If this analysis be accepted, it follows that the purchaser has an equitable property right amounting to substantial ownership, and this though time is expressly of the essence, though prompt payment is stated to be a condition precedent to any rights under the contract, and though the contract contains a forfeiture clause. This equitable ownership of the purchaser is subject to the security interest of the vendor, who is in a

292. Cf. Reep, Second Mortgages and Land Contracts in Real estate Financtino (1928) $1,160$.

293. Commissioners of Douglas County v. Union Pacific Ry. Co., 5 Kan. 615, 623 (1870); Brown v. Thomas, 37 Kan. 282, 286, 15 Pac. 211, 213 (1887); Pickens v. Campbell, 104 Kan. 425, 179 Pac. 343 (1919); Schaefer v. E. F. Gregory Co., 112 Wash. 408, 413, 192 Pac. 968, 971 (1920).

294. Williams v. Haddock, 145 N. Y. 144, 39 N. E. 825 (1895); 1 PoMeroy, op. dit. supra note 164, at $680 \mathrm{n}$. It is of course true that, where time is of the essence, prompt performance is a condition precedent to the vendor's duty to convey, but it is not necessarily a condition precedent to the creation of the vendor-purchaser relation.

295. Cf. Barlow v. Williams, 16 Manitoba 164 (1906). 
position in substance like that of a mortgagee. When an attempt is made by the vendor to enforce the forfeiture clause in the contract because the purchaser has failed to pay an installment on time, the problem is not simply whether equity will allow the cancellation of a contract as against one who is in default under it $^{206}$ but also whether equity will enforce a forfeiture both of the purchaser's equitable interest and of payments previously made in favor of one who has in substance only a security interest in the property. In the very similar case of a purchasemoney mortgage, the answer is clear. The mortgagee may foreclose, but he cannot forfeit the security without returning payments made less his damages, while the mortgagor has a right of redemption until foreclosed. No amount or sort of express provisions for forfeiture in the bond and mortgage can change this result. ${ }^{297}$ In the case of a land contract, while the contractual aspect of the case may well be regarded to the extent of denying specific performance to the purchaser who is in default under a clause making time of the essence, it would go directly counter to the traditional attitude of equity toward penalties and forfeitures ${ }^{298}$ to permit the vendor to retain payments made by the purchaser over and above the vendor's actual or reasonably liquidated damages. As the Judicial Committee of the Privy Council has forcibly pointed out in the comparatively recent case of Steednan v. Drinkle, the proper course for equity to pursue is to refuse specific performance to the purchaser if the vendor objects, but in such case to allow the purchaser to recover his payments less the vendor's damages resulting from the purchaser's failure to carry out his contract. 300

The reasons which have led many if not most American courts to a contrary conclusion ${ }^{301}$ are more easily comprehended than justified. For one thing, the attention of the courts has ordinarily been directed rather toward the question of whether the purchaser in default should be granted specific performance than toward the quite different question of whether payments already made should be forfeited. ${ }^{302}$ Moreover, there has been confusion as to whether the purchaser under a contract making time of the essence gets an immediate equitable property right, ${ }^{503}$ and an uncritical assumption of the enforceability of contract provisions put in the form of "conditions precedent" regardless of the fact that the en-

296. Cf. Bodwell v. Bodwell, 66 Vt. 101, 104, 28 Atl. S70, 871 (1894).

297. See 3 Ponmeroy, op. cit. supra note 164 , at $\$ 1193$.

298. See 5 Holdsworth, History of Exiglish Law (1924) 293 et seq.

299. [1916] 1 A. C. 275, (1916) 29 HaRv. L. REv. 791.

300. But cf. 2 Winuston, Contracts (1920) 1517.

301. See notes 313,315 , infra.

302. See, e.g., Heckard v. Sayre, 34 III. 142, 149 (1864).

303. See note 293 , supra. Cf. Williams v. Williams, 50 Wis. $311,315,6$ N. W. 314,316 (1880). 
forcement of such provisions will result in forfeitures. ${ }^{304}$ But the basic reasons behind the prevailing American rule lie deeper than this. The doctrine that equity will enforce forfeiture provisions in land contracts where time is expressly made of the essence developed in this country during the latter half of the nineteenth century, ${ }^{305}$ at a time when extreme ideas as to "freedom of contract" were influencing American judicial decisions in every field. ${ }^{306}$ It was a time when equity was decadent, ${ }^{307}$ when laissez faire was almost an article of judicial faith, ${ }^{308}$ and when the courts were thinking in terms of free-willing individuals entirely able to look after themselves rather than in terms either of classical equity or of a socialized law taking a realistic account of inequalities of economic position and bargaining power. The ecclesinstical chancellor who granted relief to a plaintiff who had not taken care to follow the prescribed rules as to covenants because "Deus est procurator fatuorum,",309 the classical chancellor who created the equity of redemption in the face of the strict $\mathrm{law}^{310}$ and who said that "necessitous men are not . . . free men,"311 had given place to judges who regarded individual freedom of contract as fundamental in any civilized system of law and enforced the harshest of contract provisions without hesitation or searching of conscience unless constrained by binding precedent to relieve against them. The court of conscience had become a court strictissimi juris. ${ }^{312}$ In such an atmosphere, it was easy enough to put aside the tradition that equity would not enforce a forfeiture except in so far as that tradition had been embalmed in direct precedents, and to develop a line of decisions holding that contracts for the sale of land which expressly made time of the essence and provided for the forfeiture

304. See, e.g., Labelle v. O'Connor, 15 Ont. L. R. 519, 542 (1908); Pomerox, Spectric Perporacance of Contracts (3d ed. 1926) $\$ 379$. There should be no such magic in the words "condition precedent."

305. Compare Heckard v. Sayre, 34 III. 142 (1864) with Edgerton v. Peckham, 11 Paige 352 (N. Y. 1844).

306. See Pound, Liberty of Contract (1909) 18 Yare L. J. 454. Cf. Jennings, Freedom of Contract-Inquiries and Speculations (1934) 22 CALrF. L. REv. 636.

307. See Pound, The Decadence of Equity (1905) 5 Cor. L. REv. 20.

308. See note 306, supra. Cf. Holmes, J., dissenting, in Lochner v. New York, 198 U. S. 45,75 (1905).

309. George Neville, Bishop of Exeter, L. C., in Y. B. Pasch. 8 EDw. IV, f. 4, pl. 11 (1467); see Vinogradoff, Reason and Conscience in Sixteenth-Century Jurrisprudence (1908) 24 L. Q. REv. 373, 380.

310. See 5 HorDSWORTH, op. cit. supra note 298 , at 330.

311. Lord Northington, L. C., in Vernon v. Bethell, 2 Eden 110, 113 (Ch. 1762).

312. Cf. Buckley, J., in In re Telescriptor Syndicate, Ltd., [1903] 2 Ch. 174, 195: "This Court is not a Court of conscience." For a very recent example of this tendency, seo Graf v. Hope Bldg. Corp., 254 N. Y. 1, 171 N. E. 884 (1930); and cf. the comment on that case in (1930) 79 U. OF PA. L. Rev. 229, 231. 
of all payments theretofore made in the event of default would be enforced according to their literal terms, ${ }^{313}$ especially where prompt payment of all installments was made an express "condition precedent" to the purchaser's rights under the contract. There has been some slight tendency away from this nineteenth century doctrine in the last few decades, ${ }^{314}$ but it has become established law in many American states. ${ }^{315}$

In this situation, where courts of equity have tied their own hands by a line of inequitable precedents, the case for corrective legislation seems clear-and there has been some such legislation. To a considerable extent, however, the courts have succeeded in depriving of effect the statutes which have been enacted to compel them to do equity. The broad provisions of the Field draft Civil Code, ${ }^{310}$ adopted in California, Montana and North and South Dakota, authorizing relief against forfeitures $^{317}$ have been held in California to be inapplicable to land contracts where time is of the essence. ${ }^{318}$ Statutes providing for a period of

313. Some of these decisions have resulted in shocking hardship on the purchasar. See, e.g., Iowa Rr. Land Co. v. Mickel, 41 Iow3 402 (1875); Hecliard v. Sayre, 34 III. 142 (1S64); Nelson Real Estate Agency v. Seeman, 147 Minn. 354, 180 N. W. 227 (1920); Brown v. Ulrich, 48 Neb. 409, 67 N. W. 168 (1896); Doctorman v. Schroeder, 92 N. J. Eq. 676, 114 Atl. 810 (1921).

314. See, e.g., Lytle v. Scottish American Miortgage Co., 122 Ga. 458, 467, 50 S. E. 402,406 (1905). There has also been a tendency on the part of some courts which enforce forfeitures to avoid doing so in hard cases by finding a "waiver" of the forfeiture by the vendor. As has aptly been said, "Strict doctrines as to forfeiture inevitably produce loose doctrines as to "waiver'." Pound, supra note 164, at 952.

315. The authorities are collected and ably discussed in Ballantine, Forfeiture for Bresel: of Contract (1921) 5 Mmax. L. REv. 329; Corbin, Right of a Defaulting Vendee to tle Restitution of Instalments Paid (1931) 40 YAIE L. J. 1013; Vanneman, Strict Foredostare on Land Contracts (1930) 14 MInN. L. REv. 342.

316. \$ 1831: "Whenever, by the terms of an obligation, a party thereto incurs a forfeiture, or a loss in the nature of a forfeiture, by reason of his failure to comply with its provisions, he may be relieved therefrom, upon making full compensation to the other party, except in case of a grossly negligent, willful or fraudulent breach of duty." Sre also $\$ 1883$, providing that "neither specific nor preventive relief can be granted to enforce

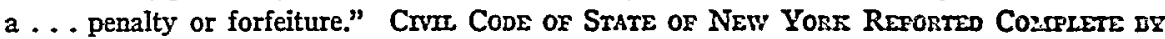
THE COMOAISSTONERS of THE CODE (1865) 564, 583. This code, prepared by David Dudley Field and A. W. Bradford, was never adopted in New York, but was adopted in Califomiz, Montana and North and South Dakota. Cf. Poond, Outromes of Lecrunes o: JuruspavoENCE (4th ed. 1928) 83 .

317. Cal. Crv. Code (Deering, 1931) $\$ \S 3275,3369$; Mo:vr. Rev. Cone Arr. (Choste, 1921) $\S 8658,8710$; N. D. Cosrr. Laws AwN. (1913) §§ 7138, 7188; S. D. Cosm. Laws (1929) $\S \S 1958,2006$.

318. Parsons v. Smilie, 97 Cal. 647, 654, 32 Pac. 702, 704 (1893); Glock v. Howard \& Wilson Colony Co., 123 Cal. 1, 55 Pac. 713 (1S98); Collins v. Elisoozian, 61 Cal. App. 184, 196, 214 Pac. 670, 675 (1923); (1930) is Carm. L. Rev. 681; Comment (1932) 20 id. at 194. Montana appears to have taken a somewhat more liberal view. Cf. Surburban Homes v. North, 50 Mont. 10S, 145 Pac. 2 (1914). In South Dakota, these provisions, while not restricted in their application to such an extent as in California, do not prevent 
grace to the purchaser in the termination of land contracts ${ }^{310}$ have been construed, ${ }^{320}$ contrary to what appears to have been the intent of the legislature, ${ }^{321}$ as if enacted for the sole purpose of giving vendors an effective remedy without the need of going through foreclosure proceedings. ${ }^{322}$ In Canada, on the other hand, relatively simple legislation ${ }^{\text {gag }}$ has been surprisingly effective, ${ }^{324}$ emphasizing that the difficulty in securing a similar result in this country has been caused primarily by the courts. Recent moratorium legislation has in at least one instance included land contracts ${ }^{325}$ and seems sustainable under the federal Consti-

forfeiture of payments where the vendor sues to quiet title against the contract or for strict foreclosure. Pier v. Lee, 14 S. D. $600,606,86$ N. W. 642,643 (1901); Taylor v. Martin, 51 S. D. 536, 215 N. W. 695 (1927). The North Dakota court has not yet definitely settled the construction to be given to such provisions in that state. Cf. Bennett v. Glaspell, 15 N. D. 239, 107 N. W. 45 (1906); Johnston Farm Investment Co. v. Huff, 52 N. D. 589,204 N. W. 333 (1925). See, generally, Vanneman, supra note 315, at 353-358. With regard to other legislation as to land contracts in North and South Dakota, sce note 319, infre.

319. The Minnesota statute is typical. It provides: "When default is made in the conditions of any contract for the conveyance of real estate or any interest therein, whercby the vendor has the right to terminate the same, he may do so by serving upon the purchaser ... a notice specifying the conditions in which default has been mado, and stating that such contract will terminate thirty days after . . . such service unless prlor thereto the purchaser shall comply with such conditions and pay the costs of service. . . . If within the time mentioned, the person served complies with such conditions and pays the costs of service, the contract shall be thereby reinstated; but otherwise shall terminate." Menn. Stat. (Mason, 1927) \& 9576. A similar statute is in force in Iowa. Iown Code (1931) §§ 12389-12394. In North Dakota, there is a statute having a like efiect but requiring one year's notice. N. D. CoMrp. LAws ANN. (1913) $\S \S 8119-8122$, as amended by N. D. Cosap. Laws ANN., 1913-1925 (Supp. 1926) \$§ 8122-8122a. In South Dakota, there is a statute codifying a strict foreclosure procedure but empowering the court "to equitably adjust the rights of all the parties." S. D. Comp. Laws (1929) $\$ \S 2914-2917$. This statute has had little effect. Cf. Hickman v. Long, 34 S. D. 639, 150 N. W. 298 (1914); Scott v. Hetland, 51 S. D. 303, 213 N. W. 732 (1927); Vanneman, stipra note 315, at 365-36\%.

320. International Realty Co. v. Vanderpoel, 127 Minn. 89, 148 N. W. 895 (1914); Nelson Real Estate Agency v. Seeman, 147 Minn. 354, 180 N. W. 227 (1920); Note (1921) 5 Mrnw. L. Rev. 466. The Iowa court has been less severe. See Waters v. Pearson, 163 Iowa 391, 144 N. W. 1026 (1914). But cf. Mintle v. Sylvester, 202 Iowa 1128, 211 N. W. 367 (1926) (with dissent on another point), discussed in Note (1927) 13 Iowa L. REv. 93. North Dakota, however, appears to have taken much the same view as Minnesota. Lander \& Co. v. Deemy, 46 N. D. 273,176 N. W. 922 (1920) (with dissent). See, generally, Vanneman, supra note 315 , at 362-365.

321. Ballantine, supra note 315 , at 351 .

322. Vanneman, supra note 315 , at 363-364.

323. Alberta Rev. Stat. (1922) c. 72, § 35(h); SasK. Rev. Stat. (1930) c. 86, §§ 2-3.

324. See Canadian Pacific Ry. v. Meadows, 1 Alberta L. R. 344 (1908) (with dissent as to extent of relief given); Mortgage Co. of Canada v. Filer, 18 Alberta L. R. 367 (1922); Provincial Securities Co. v. Gratias, 12 Sask. L. R. 155 (1919); Ballantine, supra note 315, at 351 , et seq.

325. Minn. Laws 1933, c. 422. 
tution on the same basis as similar legislation as to mortgages. ${ }^{320}$ But the real need is for carefully drafted statutes, the effect of which the courts will be unable to evade, and which will compel them to deal with installment contracts for the sale of land on the same equitable principles which they apply without hesitation in the case of transactions essentially similar in economic substance but set up in the form of a conveyance on credit with a mortgage back as security. ${ }^{32 \pi}$ Such legislation would bring about the result which should have been reached by the courts themselves through a proper application of the theory of equitable conversion and the principle of relief against forfeitures. This would seem to be a matter which might appropriately engage the attention of the National Conference of Commissioners on Uniform State Laws or other appropriate body. ${ }^{328}$

\section{VI \\ By Way of Conclusion}

It remains to consider the significance and implications of the legislative changes in the law of equitable conversion by contract which have been the subject of this discussion. From a purely analytical standpoint, they indicate mainly a shift in emphasis in this field from the unwritten to the written law, with some modification of doctrine. There once we had a group of legal precepts developed logically from certain basic theoretical conceptions to be found in the decisions of the courts, we now have a somewhat different group of precepts which have been supplied in part by the legislature. The analytical jurist must take account of these changes and must work them into his system of the law as it is. When, however, the law is looked at as an evolving social institution, the legislation in the field of equitable conversion has a larger importance than this. The legislative changes which have been discussed are collectively significant as one more indication of the shift from equity

326. See Home Bldg. \& Loan Ass'n. v. Blaisdell, 290 U. S. 398 (1934), holding constitutional Minn. Laws 1933, c. 339. Cf. W. B. Worthen Co. v. Thomas, 292 U. S. 426, 432 (1934).

327. This would not necessarily result in treating the two situations exactly alike. In the mortgage situation, the buyer has the land and is not seeling afirmative relief, so that the only question is as to relief against forfeiture. In the Ind contract situation, the buyer is seeking legal title when in default under his contract. While he should bz relieved against forfeiture on analogy to the mortgage situation, there seems no compalling reason for allowing him to have specific performance if the seller objects. See Comment (1922) 32 YaLE L. J. 65. This is the result which the English courts have reached without statutory aid. Steedman v. Drinkle, [1916] 1 A. C. 275, stcpra note 299. Compare In re Dagenham (Thames) Dock Co., 8 Ch. App. 1022 (1S73), and Filmer v. British Columbis Orchard Lands, Ltd., [1913] A. C. 319, where specific performance was granted to a purchaser in default although time was expressly of the essence of the contract.

32S. Cf. the preceding installment of this article (1935) 44 YaLE L. J. 559, 563, 571. 
to legislation as the principal means of legal growth ${ }^{320}$ - of the increasing supersession of the judge by the legislator in the shaping of the legal order. To the teacher of law, who must consider both the analytical and the evolutionist viewpoints, it must be apparent that in the field of equitable conversion, as in other fields, he must increasingly concern himself with statutes. 330

The legislative changes which have been here reviewed will, however, have perhaps the greatest significance for those of the bench and bar who are concerned with making the law more effective in attaining social ends-for the lawyer as social engineer. ${ }^{331}$ In the domain of property law, one desideratum is reasonable certainty, and in attaining certainty the method of logical deduction by which the rules of equitable conversion were developed would at least seem to have much to commend it. But it must be recognized that no ideal state of certainty has in fact been reached by this method; ${ }^{332}$ and, in any event, certainty at the expense of justice, elegantia juris at the expense of practical wisdom, may come too high. In modifying the logical structure of the law to meet the needs of practical affairs and the ideals of justice of the time and place, legislation has the great advantage of laying down a rule for the future in a specific situation without affecting vested rights and without disturbing the certainty of existing law as applicable to other situations, in so far as such certainty exists. In the particular field of the law here under discussion, it has been possible to make numerous legislative changes without abolishing entirely the doctrine of equitable conversion, which still remains available as a legal tool.

There would seem to be no present necessity for a general legislative overhauling of the law of equitable conversion by contract. Where the rules which have been developed on the basis of the theory of conversion operate unjustly, where they produce results which are inconsistent with the economic and social ideals of the time, appropriate statutory changes in particular rules should take care of the matter. There is need for careful drafting of such statutes. Corrective legislation, while it may be enacted piecemeal, should not be haphazard. But the time has hardly come for the abolition of the doctrine of equitable conversion or for its codification. Nor does it seem of essential importance that the law as to

329. Cf. Marne, Anctent Law (10th ed. 1906) 29.

330. Cf. Simpson, The Use of Statutory Materials in the Teaching of Equity (1933) 21 Geo. L. J. 457.

331. Cf. Pound, Interpretation or Legal History (1923) 152 et seq.

332. Cf. the conflicting lines of decisions on particular applications of the doctrine of equitable conversion referred to in notes 164-180, 188-202, 237-238, 313-315, supra, and in the preceding installment of this article, (1935) 44 YALE L. J. 559, notes $25,32-33,55$, 93-94, 128-132. 
those matters to which the doctrine relates shall be made uniform as between the states. Equitable conversion is primarily a conception of the law of real property. The matters to which it relates-descent and distribution, dower and curtesy, rights of creditors against interests in land held by their debtor, vendor and purchaser-are of peculiarly local importance and character. Until an attempt is made to make uniform the decedent estates statutes and the real property law of the several states, there seems no necessity for making uniform the law of equitable conversion; and such an attempt appears even more remote than codification of real property law in the individual states. ${ }^{333}$ The recent proposal of a Uniform Vendor and Purchaser Risk Act, ${ }^{334}$ for example, may be supported as a measure of law reform, provided one is convinced of the superiority of the Act's solution of the problem of burden of loss as between vendor and purchaser over the other solutions which the courts have adopted; ${ }^{335}$ it seems difficult to justify the proposed statute as a measure "to promote uniformity in state laws on ... [a subject] where uniformity is deemed desirable and practicable..333 But there is need in every state for critical analysis of the existing legal rules which have been developed on the basis of the conversion doctrine and for the preparation and enactment, wherever appropriate, of wisely conceived and carefully drafted corrective legislation. The legislative changes of the past point the way to further conscious improvement in this important corner of the law.

333. Cf. Fraser, The Unfortunate Statiw of Certain Factors of Real Proferty La:o and Suggested Remedies (1934) 20 A. B. A. J. 684.

334. See pp. 769-773, supra.

335. See notes 164-180, supra.

336. Constitution of the National Conference of Commissioners on Uniform State Laws,

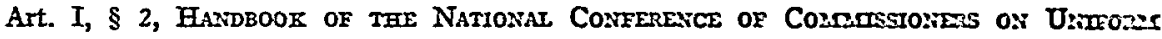
State Laws (1933) 468. 